\title{
技術資料
}

UDC $669.14: 629.113$

\section{自動車用特殊鋼の最近の動向 (2)}

加藤 哲男* . 阿部山尚三*2 $・$ 上原 紀興*2

\section{Recent Trends in Special Steels for Automobiles}

\author{
Tetsuo Kato, Shozo Abeyama, and Norioki Uyehara
}

\section{3.ばね鋼}

自動車用の板ばねとコイルばねには，従来主として SUP 6(0.6C-1.65Si-0.85Cr) が使用され，板厚の大き いばね用としては一部に焼入性の高い SUP 9(0.55C$0.25 \mathrm{Si}-0.8 \mathrm{Mn}-0.8 \mathrm{Cr}$ ) や SUP 11 (SUP 9+B) などが 使用されていた．しかし近年，とくに乗用車の軽量化と 乗心地の向上をはかるために，後輪懸架も板ば齐からコ イルばねに変更される傾向にあり，それに伴つてばね用 材料もより耐へたり性の良好な材料が求められるよらに なつた。 そのため自動車用熱間成形ば就鋼はSUP 6 か らしだいに Si 量の高いSUP $7(0.6 \mathrm{C}-2.0 \mathrm{Si}-0.85 \mathrm{Cr})$ に移行する動きがある. Si は Fig. 1264) に示すよう に, 焼もどし軟化抵抗を高めて耐へたり性を向上するの に有効な元素である. その反面, SUP 7 はSUP 6 に 比較して黒鉛化や脱炭を起こしやすいので, 素材の製造 にあたつては圧延および熱処理条件の適正化など，入念 な注意が払われている。

また高強度化に伴つて疲労破壊に対する信頼性を確保 することもますます重要となるが，これに対しては $2 \cdot 2$ .2 項で述べた真空脱ガス処理を行い, 非金属介在物量 を減少させる対策がとられている.

また軽量化と乗心地向上のために, ばねの形状につい ても新しいくふらが行われつつあり，いわゆるテーパー リーフばねやテーパーュイルばね被(66) の採用も始まつて
いる。これらのばねに使用される不等断面素材は，現在 特殊な圧延や切削によつて製造されているが，より低廉 な製造法の開発が必要とされている.

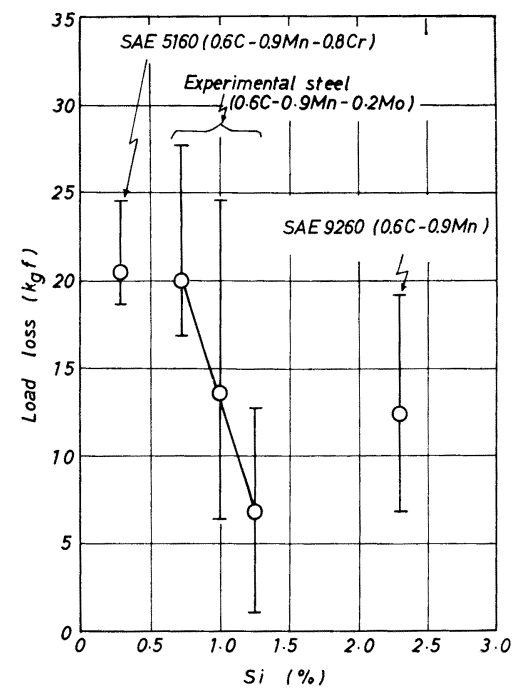

Fig. 12. Effect of silicon on load loss of spring steels ${ }^{64}$.

昭和 55 年 9 月 25 日受付 (Received Sept. 25, 1980) （依頼技術資料）

* 大同特殊鋼 (株) 中央研究所工博 (Central Research Laboratory, Daido Steel Co., Ltd.)

*2大同特殊鋼 (株) 中! 央研究所 (Central Research Laboratory, Daido Steel Co., Ltd., 2-30 Daido-cho Minami-ku Nagoya 457)

自動車用特殊鋼の最近の動向（1）は鉄乙鋼 Vol. 67 No. 9 に揭載，目次は以下のと打り

1. 緒 $\overline{\overline{\bar{े}}}$

2. 機械構造用鋼

2.1 概観

2.2 製造技術の進步

2.2 .1 電気灿製鋼技術 2.2.2. 灯外精錬技術 2.2 .3 連続鋳造 2.2.4. 压延技術

2.2 .5 検査整備技術

2.3 新鋼種の開発

2.3 .1 省資源型新鋼種（省Mo 強靱鋼，省 Mo はだ焼鋼）

2.3 .2 省エネルギ型新鋼種（鍛造用非調質強鞋鋼，短時間浸炭用鋼）

2.3 .3 部品加工合理化のための新鋼種（快削鋼，冷鍛用鋼，低熱処理変形鋼） 


\section{4. 耐 熱 材 料}

\section{1 概 観}

1970 年に始まつた日本国内のガソリンの無鉛化はエ ンジン・バルブおよびバルブ・シート材料にその対策を 促し, また 1966 年以降 1978 年に至る段階的な排出ガ ス規制に対処するため, サーマル・リアクタ一や触媒コ ンバーターなどの浄化機器や副燃焼室式のエンジン等が 開発され，排出ガスによる高温腐食という新しい観点か らの材料開発を必要とした. さらに 1979 年の第 2 次才 イルショックを契機として燃費の向上が大きくクローズ アップされて, 小型のディーゼル・エンジンやターボチ ャージャーが登場し, これらに使用される耐熱材料の開 発も引続き行われている，また一方で，1978 年のCo原 料の価格高騰は耐熱材料に多用されているCo の省略と いつた，上記とは別の次元からの材料開発をも必要と した.これらの自動車用耐熱材料の中で, エンジン・バ ルブ材料や排出ガス浄化機器用材料についてはすでに詳 しい解説があるので67) 69), 本稿では最近のトピックス 的な項目をとりあげることにしたい。

\section{$4 \cdot 2$ エンジン・バルブ用耐熱材料}

\section{$4 \cdot 2 \cdot 1$ 吸気バルブ用材料}

従来はガソリン・エンジンおよびディーゼル・エンジ ンとも吸気バルブには SUH $3(0.4 \mathrm{C}-2 \mathrm{Si}-11 \mathrm{Cr}-1 \mathrm{Mo})$ が主として使用されてきたが，この数年，乗用車用ガソ リン・エンジンには次第に SUH 11 (0.5C-1.5Si-8.5 Cr）が使用される傾向にある。これは OHG（オーバー ヘッド・カムシャフト) 型エンジンが増加するととも に, バルブ・ロッカー・アームがアジャスト・スクリュ ウ形式となつたために, 軸端の耐摩耗性をより高める必 要が生じ ${ }^{68)}$, SUH 3 より C 量が高く, 焼入硬さの高い SUH 11 に移行しているものである。

いつぽら米国では SAE 1541(0.4C-1.5Mn)などの低 合金鋼が主として使用されている．低合金鋼はSUH 11 に比較して $\mathrm{PbO}$ 等に対する耐食性や, 高温強度・軸端 硬さなどが劣るので, 回転数などのエンジン設計仕様が 厳しく，また有鉛ガソリン地区を含む輸出が多いわが国 の乗用車に直ちに塔載するのは困難と思われるが，今後 検討が行われるであろら.

$4 \cdot 2 \cdot 2$ 排気バルブ用材料

排気バルブの作動温度は $600 \sim 850^{\circ} \mathrm{C}$ 前後であり ${ }^{69)}$,
そのためバルブ材料には高温での耐摩耗性，疲労強度な らびに耐食性が, 必要とされる。 そこで現在ではガソり ンならびにディーゼル・エンジンとも SUH 35(0.55C$9 \mathrm{Mn}-4 \mathrm{Ni}-21 \mathrm{Cr}-0.4 \mathrm{~N})$ およびその改良鋼が主として使 用され，また傘部周用には耐摩耗性と耐食性を高めるた めに Co 基合金を肉盛溶接する場合が多い。この排気 ルブ用材料については, 最近の Co 価格高騰を契機とし て新たな技術開発が行われている.すなわち，ひとつは Co 基合金の肉盛溶接を省略する方向であり，そのため にCo基合金にほぼ匹敵する高温硬さを有する $\mathrm{Ni}$ 基合金 をバルブ本体に使用する考方方であり，一部の乗用車用 ガソリン・エンジンに使用されている. Table 4 に排気 バルブに使用される $\mathrm{Ni}$ 基合金の化学成分の例, Fig. 13 にそれらの高温硬さを示す。 また Ni 基合金は Fig. 14 に示すように，従来の排気バルブ用鋼にくらべて高温疲 労強度が著しく高いことが評価され，バルブの耐久性を 特に必要とされるディーゼル・エンジンへの適用も検討 されている. しかしこれらの $\mathrm{Ni}$ 基合金は従来材に比較 するとかなり高価であるので，今後 $\mathrm{Ni}$ 基合金に匹敵す

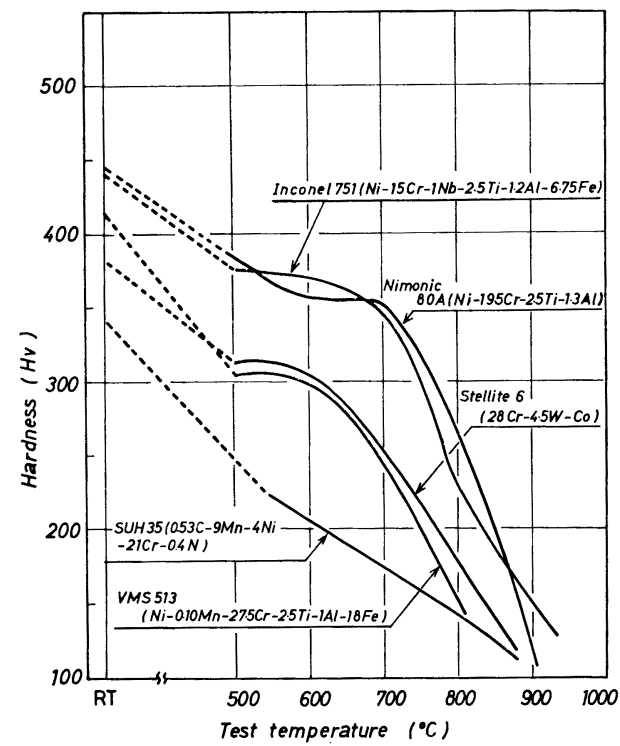

Fig. 13. Hardness of exhaust valve materials at elevated temperature.

Table 4. Ni-base alloys for exhaust valves.

\begin{tabular}{l|c|c|c|c|c|c|c|c|c|c|c}
\hline \multicolumn{1}{c|}{ Notation } & $\mathrm{C}$ & $\mathrm{Si}$ & $\mathrm{Mn}$ & $\mathrm{Ni}$ & $\mathrm{Cr}$ & $\mathrm{Nb}$ & $\mathrm{Ti}$ & $\mathrm{Al}$ & $\mathrm{Co}$ & $\mathrm{Fe}$ & $\mathrm{B}$ \\
\hline Inconel X-750* & 0.04 & 0.30 & 0.70 & $\mathrm{bal.}$ & 15.0 & 0.85 & 2.5 & 0.8 & - & 6.75 & - \\
Inconel 751 & 0.04 & 0.30 & 0.70 & $\prime \prime$ & 15.0 & 1.0 & 2.5 & 1.2 & - & 6.75 & - \\
Nimonic 80A & 0.06 & 0.70 & 0.10 & $\prime \prime$ & 19.5 & - & 2.5 & 1.3 & 1.1 & 2.4 & - \\
VMS 513 & 0.08 & 0.10 & 0.10 & " & 27.5 & - & 2.5 & 1.0 & - & 18.0 & 0.006 \\
\hline
\end{tabular}

* JIS NCF 3 B 


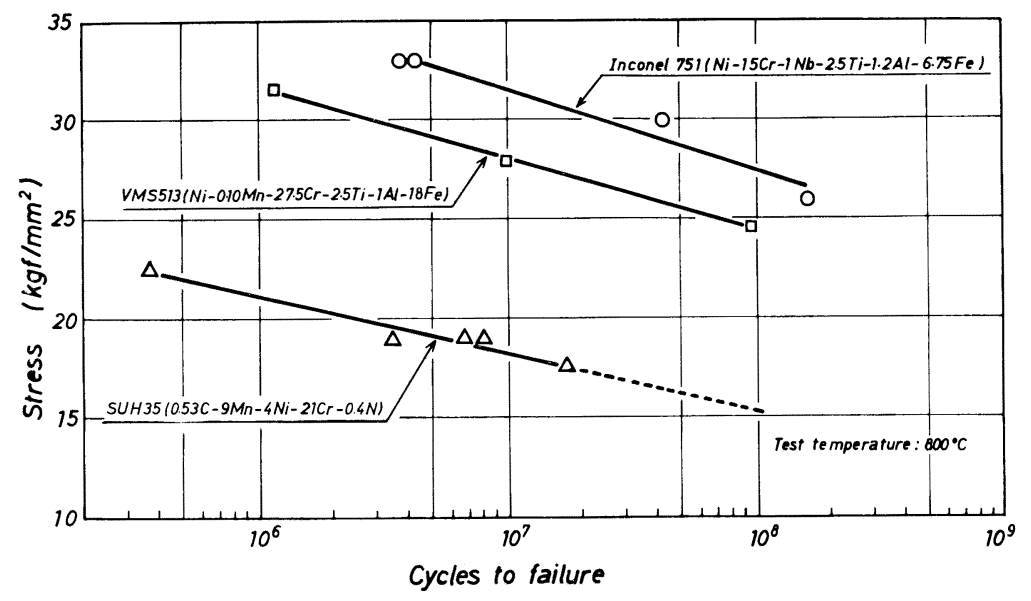

Fig. 14. Fatigue strength of exhaust valve materials at elevated temperature.

Table 5. Hard-facing materials for exhaust valves.

\begin{tabular}{l|c|c|c|c|c|c|c|c|c}
\hline \multicolumn{1}{c|}{ Notation } & G & Ni & Gr & Co & Mo & W & Fe & B \\
\hline Stellite 6 & 1.15 & 3.0 max. & 28 & bal. & 1.5 max. & 4.5 & 3.0 max. & - \\
Stellite 12 & 1.35 & 3.0 max. & 30.5 & bal. & - & 8.5 & 3.0 max. & - \\
Stellite F & 1.75 & 22.5 & 25 & bal. & 0.6 & 12.3 & 1.0 & - \\
Eatonite & 2.4 & bal. & 29 & 10 & - & 15 & - & - \\
Haynes alloy 716 & 1.1 & 22 & 26 & 12 & 3 & 3.5 & bal. & 0.4 \\
\hline
\end{tabular}

Table 6. Examples of valve seat materials for gasoline engines75).

$(\mathrm{wt} \%)$

\begin{tabular}{|c|c|c|c|c|c|c|c|c|c|c|}
\hline Material & C & $\mathrm{Si}$ & Mn & $\mathrm{Cr}$ & $\mathrm{Ni}$ & Co & Mo & W & $\mathrm{Fe}$ & Others \\
\hline $\mathrm{P} / \mathrm{M}$ alloy $(1)$ & 1.4 & - & - & 8.0 & 2.0 & 9.0 & 0.5 & 3.0 & bal. & - \\
\hline $\mathrm{P} / \mathrm{M}$ alloy (2) & 1.0 & - & - & 3.0 & - & - & 0.3 & - & "I & $\mathrm{Pb} 10 \mathrm{~min}$ \\
\hline $\mathrm{P} / \mathrm{M}$ alloy $(3)$ & 1.0 & - & - & 20.0 & 12.0 & - & 2.0 & - & " & $\mathrm{Pb} 4$, glass 2, $\mathrm{P} 0.3, \mathrm{~S} 0.2$ \\
\hline Wrought alloy & 1.0 & 2.0 & 0.5 & 20.0 & 0.1 & 2.0 & 1.0 & - & " & 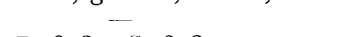 \\
\hline Cast alloy & 1.9 & 1.4 & 1.1 & 22.0 & 20.0 & 12.0 & 2.5 & 6.0 & " & $\mathrm{P} \quad 0.2, \quad \mathrm{~S} 0.2$ \\
\hline
\end{tabular}

る高温強度を有し，かつ高温での耐食性も良好な $\mathrm{Fe}$ 基 合金の開発が必要となるであろう。

また第二の方向は Co 基合金に代わる肉盛材料の開発 である、これまで我が国においては Stellite 6,12 が主 として使用されてきたが，最近では Coの一部を Niで 置換した Stellite F も使用されるよらになり ${ }^{69)}$ ，またさ らに Ni 基肉盛材料の開発も積極的に行われている.

Table 569) 72) にこれらの硬化肉盛材料の主要化学成分 を示す.

$4 \cdot 2 \cdot 3$ バルブ・シート用材料

ガソリンの無鉛化の影響が最も大きく現れたのはバル ブ・シートであつた。 バルブ・シートの温度は吸気側が $150 \sim 200^{\circ} \mathrm{C}$, 排気側が $250 \sim 350^{\circ} \mathrm{C}$ とされており ${ }^{67)}$, これまでは主として普通鋳鉄や耐熱鋳鉄が使用されてい た。しかしガソリンの無鉛化により有鉛ガソリンの燃焼
生成物 $\left(\mathrm{PbO} \cdot \mathrm{PbSO}_{4}\right.$ や $\mathrm{Pb}(\mathrm{Br}, \mathrm{Cl})_{2}$ といわれている) ${ }^{73)}$ による潤滑作用がなくなると，バルブ・シートの異常 摩耗が 発生し, バルブの突き上げ現象（バルブ・シー ト・リセッション) が発生する問題が生じた ${ }^{74)}$. リ七ッ ションを防止するためにはバルブの形状の変更やバルブ に回転を与えるなどの設計上の対策も行われたが，同時 にバルブ・シートの材質についても検討が行われた。 そ の結果, バルブ・シート材料として現在では主として焼 結合金が使用されるようになつた. バルブ・シート用の 焼結合金には多くの種類があるが，大別すると Cu や $\mathrm{Pb}$ などを添加または溶浸させたり，ガラスを混入して 自己潤滑作用を持たせた合金と, Mo や Co を添加し て，その酸化膜による潤滑作用を利用するものとがあ る. Table 6 に代表的なバルブ・シート用焼結合金の化 学成分を示す。 バルブ・シートの摩耗は, 相手となるバ 
ルブの材質やその表面処理の有無, またェンジンの燃焼 方式や燃料中の鉛の有無などによつて微妙に異なるの で, 個々のエンジン型式にあわせて, その都度適切な合 金を試行錯誤的に選択されているのが現状である.

\section{3 排出ガス浄化機器用耐熱材料}

日本に打ける排出ガス浄化機器は, 炭化水素（以下 $\mathrm{HC}$ と略記する）および CO 対策を主とした 1975 年 規制の当時はサーマルリアクター方式が主であつたが, さらに $\mathrm{NO}_{\mathrm{X}}$ 規制も加わつた 1978 年規制に対しては触 媒コンバーター方式に転換した車種が多い.サーマルリ アクターに使用される耐熱材料の開発の経緯は本誌67)を はじめ他にも ${ }^{76)}$ 解説されているので詳細を省くが, 最も 高温 (約 $1000^{\circ} \mathrm{C}$ ) にさらされるコア部には SUS 310S $(25 \mathrm{Cr}-20 \mathrm{Ni})$ が当初使用され, その後低廉な SUS XM $15 \mathrm{~J} 1(18 \mathrm{Cr}-13 \mathrm{Ni}-4 \mathrm{Si})$ が開発され，実用化された。 また 外気に接するために比較的低温のシェルには SUS 410S (低 C-13Cr) やSUS 430(18Cr) が使用されている.

触媒コンバーターは, 排出ガス中の $\mathrm{HC}, \mathrm{CO}$ および $\mathrm{NO}_{\mathrm{X}}$ を, Pt, Pt-Pd, Pd, Pt-Rh などの触媒によつて 酸化または還元して無害化するものである. 触媒コンバ ーターのコア部の最高温度は約 $600 \sim 650^{\circ} \mathrm{C}$ （セラミッ ク・モノリス方式）または約 $800 \sim 850^{\circ} \mathrm{G}$ (ペレット・ ベッド方式）とされ77)，主として SUS $304(18 \mathrm{Cr}-8 \mathrm{Ni})$ が使用される。 またシェルはサーマルリアクターと同様 に, AISI 409(11.5Cr-0.5Ti) や SUS 410S などのフ ェライト系ステンレス鋼が使用されるが，低廉化のため にクロマイズやアルミナイズなどの表面処理鋼板の使用 も始まつている. またモノリス方式のコンバーターで は, クッション・サポート用細線としては SUS 304(19 $\mathrm{Cr}-9 \mathrm{Ni})$, SUS 316(17Cr-12Ni-2.5Mo) などのステン レス鋼系の材料のほかに, Inconel X750, 751, SUH $660(25 \mathrm{Ni}-15 \mathrm{Cr}-1.3 \mathrm{Mo}-2 \mathrm{Ti}-0.3 \mathrm{~V})$, SUH $661(0.1 \mathrm{C}-$ $20 \mathrm{Ni}-21 \mathrm{Cr}-20 \mathrm{Co}-3 \mathrm{Mo}-2.5 \mathrm{~W}-1 \mathrm{Nb}-0.15 \mathrm{~N})$ などの超合 金，耐熱鋼を含めて適材の選定が急がれている.

\section{4 副燃焼室用耐熱材料}

排出ガス中の有害成分の発生を抑制すると同時に燃費 の向上を図るために，稀薄燃料を用い，かつその気筒内 への噴霧と燃焼を精密にコントロールする方式のエンジ ンが今後主要な位置を占めると予測されているが78) 79), 副燃焼室はそのための機構のひとつで，副燃焼室におい て気筒内への適切な燃焼噴霧流が作られると同時に着火 が行われる.この機構は基本的にはガソリン, ディーゼ ル両エンジンに採用が可能であるが，Fig. 15 にはガソ リン・エンジンの副燃焼室の一例を示す. 副燃焼室用材 料としては高温強度と高温耐食性のほかに，とくに耐熱 疲労性が重要視され，そのため従来から Nimocast 80 や SUH 661 などの Ni 基合金の精密鋳造品が使用され てきた. しかし最近 $0.3 \mathrm{C}-30 \mathrm{Ni}-20 \mathrm{Cr}$ 鋼81)や $22 \mathrm{Cr}$ $\mathrm{Mo} \cdot \mathrm{Nb} \cdot \mathrm{W}$ 鋼 $^{82}$ おおよび $12 \mathrm{Cr}-\mathrm{Ni} \cdot \mathrm{CO} \cdot \mathrm{Mo} \cdot \mathrm{V}$ 鋼83)など,

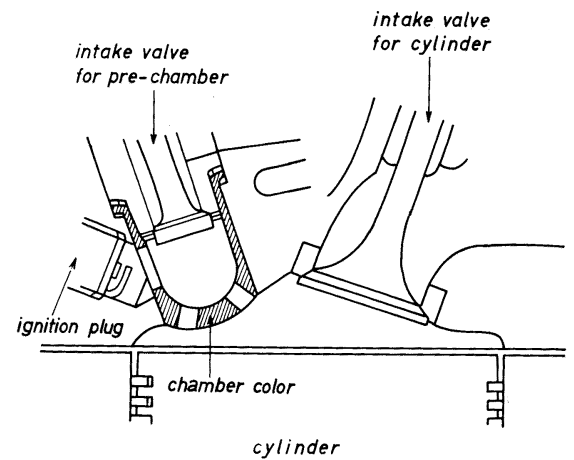

Fig. 15. An example of pre-combustion chamber (Honda, new GVCG engine),

Combustion in pre-chamber induces combustion of rarefied fuel in cylinder ${ }^{80}$ ).

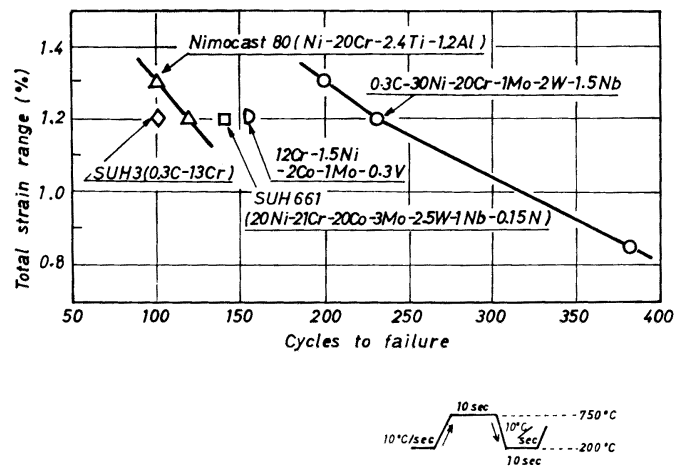

Fig. 16. Thermal fatigue characteristics of several materials for pre-combustion chamber.

$\mathrm{Ni}$ 基合金より耐熱疲労性のすぐれた Fe 基合金が開発

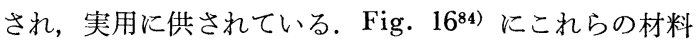
の熱疲労試験結果を比較して示す.

4.5 ターボチャージャー

ターボチャージャーは排気によつてタービンを回転さ せ，それと同軸にあるコンプレッサーによつて圧縮され た空気をェンジン内に送給し, 燃焼の効率化と出力の向 上を図ろらとするものである，従来トラックなどの大型 エンジンに採用されてきたが，最近では乗用車にも塔載 されはじめた. 今後燃費改善のためにェンジンの小型化 による出力の減少を補ら機器としてその使用が増えるも のと思われる.ターボチャージャー部品の中で最も重要 な部品は, 排気ガスを受けて最高数万〜十数万 $\mathrm{rpm}$ 程 度の高速で回転するインペラー（ホット・ホイールとも 称される）であり，クリープ強度が高いことが必要とさ れる. そこで現在では Fig. 1785) に示すように，650〜 $700^{\circ} \mathrm{C}$ 前後で最もクリープ強度の高いInconel 713C や GMR 235D 等の $\mathrm{Ni}$ 基合金が主として使用され ${ }^{86)}$, 精 密鋳造によつて製造される. 


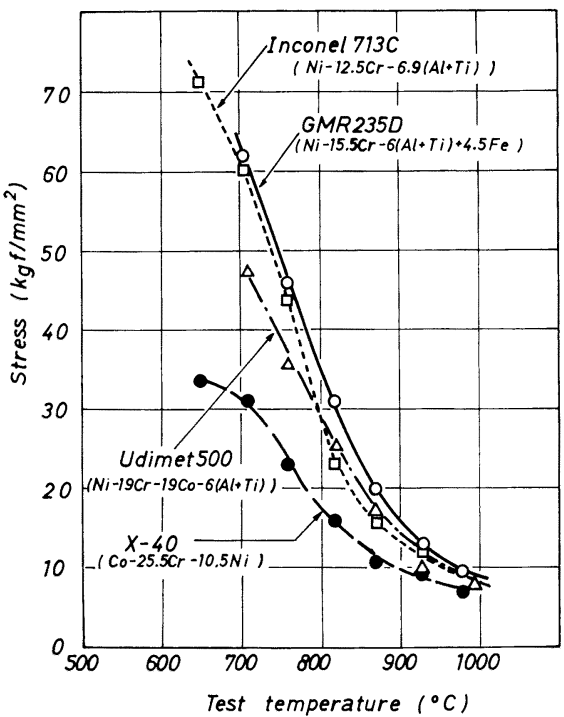

Fig. 17. Creep strength of materials for hot wheel of turbochargers ${ }^{85}$ ).

\section{5. その他の材料}

\section{$5 \cdot 1$ ステンレス鋼}

ステンレス鋼が自動車部門で消費される量は約 45000 $\mathrm{t} /$ 年 (1977年) であり ${ }^{1)}$ ，ステンレス鋼全体の約 7\%で ある.自動車におけるステンレス鋼の主な用途はトリ ム・モール，ホイール・キャップやラジオ・アンテナの よらな装飾品と， $4 \cdot 3$ 節で述べた耐熱部品である.この らち装飾部品としては後述する焼結品以外に最近見るべ き技術的進展はなく，また使用量もプラスチックをはじ め他の軽量・低廉な材料に代替されて減少しつつあり, 最近ではむしろ排出ガス浄化機器をはじめとする耐熱部 品としての重要性が増している77).

また一方で，ステンレス鋼粉末の製造技術が確立され 101)，粉治金工業会（JPMA）規格にも機械構造部品用 の焼結材料として取り上げられた. このステンレス鋼粉 末を用いた焼結品はバックミラー・サポートなどのよう な装飾品として実用化されているが87)，次のような粉末 製品ならではの用途も注目されている．すなわち原料粉 の粒度を適切に選び，圧粉と焼結工程において密度をコ ントロールすることによつて製造した耐食性のよい多孔 質体であり, 今後排出ガス浄化機器関連の各種フィルタ 一や，流量調節部品として使用が拡大することが期待さ れる ${ }^{88)}$.

\section{$5 \cdot 2$ 電磁材料}

最近の自動車のエレクトロニクス・システムの進歩に は目覚ましいものがある ${ }^{89) 90)}$ ，それは 4.4 節で述べたよ らに，然費の向上と排出ガス浄化のために，エンジンヘ
の精密な燃料供給，燃焼の制御，排出ガスの濃度や温度 の検知とその制御，といつた精密なエンジン・コントロ 一ルはもはやコンピュータ無くしては達成できないため である。ささら加えて衝突予防の安全性や，車内の居住 性の向上なども含めて，エレクトロニクス制御の必要性 は今後ともますます高まつて行くであろう。そのため 1980 年に拈ける自動車用マイクロ・コンピュータは, 全 体の数量の約 $8 \%$ を占めるのに対して, 1985 年には $26 \%$ に増加するとの予測もされている ${ }^{91)}$.

これらのマイクロ・コンピュータに使用される IC や LSI のリード・フレームには Table 7 に示す材料が使 用される ${ }^{92)}$. 今後, 広義の意味での自動車材料として欠 かすことのできない材料である.

また 4.3 節で述べたように, 今後の自動車エンジンは 気化器で空気と混合された燃料が吸気弁を介して気筒内 に送給される従来の方式から，エレクトロニクスで作動 を制御された燃料噴射装置によつて供給される方式が増 加するものと考学られるが，噴射ポンプの鉄心などには Fig. 18 に例示する被削性のよい軟質磁性材料 ${ }^{102)}$ が使 用されている.

なお電装品の各種のモーターや二輪車の発電機等に使 用される硬質磁性材料は, Co 価格高騰を機としてアル ニコ磁石からフェライト磁石へ移行する動きがあつたこ とをつけ加えておきたい。

\section{3 溶接材料}

自動車の車体はほとんどスポット溶接されるが，フレ 一ムやリヤ・アクスル・ハウジングなどは $\mathrm{CO}_{2}$ ガス被 包アークによる GMA 溶接が行われている. それに対

Table 7. Examples of materials for lead-frame of IC and LSI'92).

\begin{tabular}{l|l}
\hline Notation & \multicolumn{1}{|c}{ Chemical composition (wt \%) } \\
\hline F15 (koval) & $\mathrm{Fe}-29 \mathrm{Ni}-17 \mathrm{Co}$ \\
F 30 & $\mathrm{Fe}-42 \mathrm{Ni}$ \\
CA110 & $\mathrm{Cu}$ \\
CA194 & $\mathrm{Cu}-2.35 \mathrm{Fe}-0.12 \mathrm{Zn}-0.03 \mathrm{P}$ \\
CA195 & $\mathrm{Cu}-1.50 \mathrm{Fe}-0.88 \mathrm{Co}-0.55 \mathrm{Sn}-0.10 \mathrm{P}$ \\
\hline
\end{tabular}

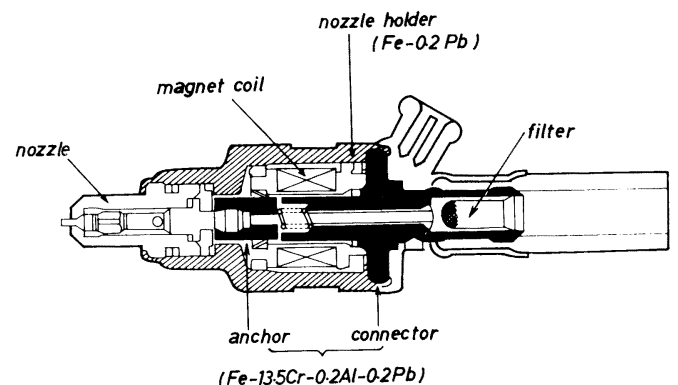

Fig. 18. Free-machining soft magnetic materials used for a fuel injection pump. 
して $\mathrm{Ar}-\mathrm{CO}_{2}$ 中で溶接を行うと溶接条件（電流, 速度) が $\mathrm{CO}_{2}$ 中の場合よりも払大できて作業能率を向上させ ることができ，またスパッタが少ないのでビードが美麗 であるなどの利点があり ${ }^{93)}$ ，欧州を中心に普及しはじめ ていた．わが国でも，近年 Ar ガスの価格が合理化され て $\mathrm{Ar}-\mathrm{CO}_{2}$ ガス溶接（これを Metal Active Gas Arc Welding-MAG 溶接と称する) のコストが $\mathrm{CO}_{2}$ ガス 溶接に比肩しうるまでに達し，注目を集めている。すで に MAG 溶接に適した溶接材料も開発されており ${ }^{94)}$, 今後の展開が期待されている.

\section{4 合金鋼焼結部品}

鉄系粉末をベースにしたプレミックス粉末による焼結 部品は, 現在タイミング・ベルト・プーリーやスプロケ ットなどのエンジン周辺の一部の部品に使用されてい る.これに対して合金鋼粉末を用いた燒結部品について は，焼結鍛造によつてコネクチング・ロッドやある種の 歯車などを製造する研究も行われ95)，技術的にはすでに かなり高い水準に達したとされているが実用化は必ずし もはかばかしいものとはいえない. 粉末焼結プロセスが 従来の棒・線材を素材とする部品加工プロセスに比較し て, 機械加工の省略・材料歩留りの向上・素材製造過程 における省エネルギなど，すぐれた特徴帛をを有しながら その普及が十分でない原因は，原料粉のコストが高いこ とにあることは大方の指摘するところである ${ }^{87)}$. ちなみ に焼結材が棒・線材を素材とする部品とコスト的に競合 できる製品重量の限界は，鉄系粉を使つた焼結の場合で $800 \mathrm{~g}$, 合金鋼粉を使つた焼結鍛造品で $250 \mathrm{~g}$ との試算結 果もある ${ }^{97)}$. したがつて今後は原料粉の製造コストの低 減と，低廉な合金組成を有する合金粉の開発が必要とな ろう。いつぽう，高速度鋼粉を使用した焼結品（あるい は焼結鍛造品）は, 溶製材にくらべて炭化物が著しく微 細・均一であるために ${ }^{98)}$ ，転動疲労寿命が良好である. このためディーゼル・エンジンの噴射ポンプのカム・リ ングとして米国で実用化されており ${ }^{99)}$, 今後軸受や耐摩 耗性部品として用途が拡大するものと思われる.このよ らに, 自動車用の焼結部品は鉄粉あるいは低合金鋼粉を 使用した機構部品と，ステンレス鋼粉や高速度鋼粉など の高合金鋼粉を使用した耐熱・耐摩・フィルターなどの 特殊部品との二本立てで今後の実用化が推進されること になろら。

\section{6. 今後の展望}

今後の自動車構成材料の変化については種々の予測が 行われているが，ほとんどは「軽量化」の観点から予測 されている. その一例を Fig. 19 に示す100)。この予測 では 1980 年から 1990 年の間に乗用車と小型トラック の平均重量は約 $25 \%$ 減少し, それを構成する材料の中 ではプラスチック打よび $\mathrm{Al}$ 合金の比率が増加するとし ている. 鉄鋼材料の構成比率はほとんど変化しないが,
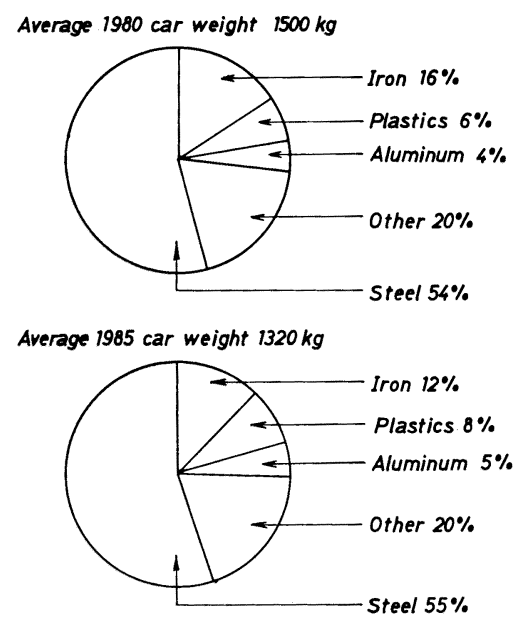

Average 1990 car weight $1130 \mathrm{~kg}$

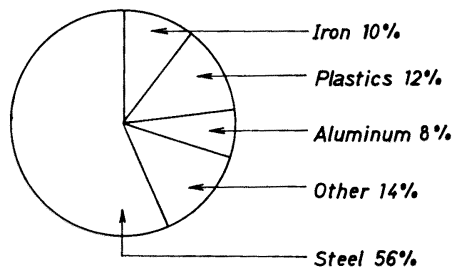

Fig. 19. Future use of materials in U.S. produced cars $^{100}$ ).

絶対量は約 $22 \%$ 減少し，それは主として車体用鋼板の 減少であると説明されている.いつぽう，すでに述べて きた自動車のエンジンや駆動系に使用される材料が車体 用鋼板と最も大きく異なる点は，これらの部品が自動車 の性能に大きく関わることと, 部品加工に要するコスト 比率が大きいことである. したがつて今後の自動車部品 材料についてはこれらの観点からも考えていく必要があ ろら．以下に筆者らの考えを簡単に述べたい。

(1) 高品質 - 高性能材料

軽量化が進むにつれてェンジン, トランスミッショ ソ，足まわり部品，軸受等の材料の作動条件は過酷にな り, それらを構成する材料には強度, 靱性, 疲労, 高温 強度，耐食性なぞの信頼性の高いことが要求される. こ れに応える材料扣よびその製造技術の開発が最も重要で あろう。

（2）部品加工の合理化

部品コストを低減させるためには, 熱処理や加工を合 理化することが最も有効であり, 本文でも述べた熱処理 の省エネルギや，快削鋼等について一層の技術開発を進 めると同時に, 精密鍛造や粉末焼結などのチップレス加 工（非切削加工）の技術開発の促進が必要である.

(3) 素材の低廉化

構造用鋼の低合金鋼化については，合金組成の開発と いら観点からはほぼ限界に近いところに到達したといえ 
よう、今後はこれらの低合金鋼をいかに使いこなして， その使用比率を拡大するかにかかつて掞り，材料技術者 と部品設計技術者との密接な連携が必要である。また本 文でも述べたように，最近多くの $\mathrm{Ni}$ 基合金などの高合 金材料が使用されはじめているが，これらについては使 用条件を見直し，それに適合する低廉材料の開発の余地 が残されているものと思われる。

\section{(4) 機能材料}

自動車部品を構成する材料の中で，物理的性能を利用 する材料が増加している. すでに本文でもマイクロ・コ ンピュータに使用される電磁材料についてふれたが, こ の他にも防振材料や各種のセンサ一等の機能材料の必要 性が増しており, 今後開拓する余地の大きな分野であ る.

\section{7. 結}

\section{言}

自動車，とくに乗用車の部品に使用される構造用鋼・ ばね鋼・耐熱材料・ステンレス鋼・電磁材料・溶接材 料・焼結部品について現状を中心に今後の動向を述べ た．項目が多岐にわたり焦点が定まつていないきらいが あるが，これでもいわゆる「特殊鋼」と称される中で軸 受鋼や，自動車生産に重要な役割を果たしている工具鋼 を省略している. このよらに数多くの材料をあえて取り あげた理由は，本文でも再々述べたように，近年の自動 車技術の目覚ましい進歩と発展に伴つて種々の新しい材 料が必要となり，自動車部品用材料が従来の構造用鋼を 中心とする「特殊鋼」の概念を大きく越していることを 述べたいと考えたからである.

今後遠からず国際的な「小型車戦争」が嬂烈になると 予想されている，日本車の性能向上のために，ますます 材料開発が重要となろうが，それには材料技術者と部品 設計技術者の密接な連携が必要であることを再び強調し て稿を終わりたい。

最後に貴重なデータを引用させていただいた各研究者 に深く感謝の意を表すると同時に，御討論いただいた日 産自動車 (株) 第 2 技術部木村茂夫氏ならびに(株)本田技 術研究所丹羽祐久氏，さらに大同特殊鋼 (株)の関係各位 にお礼を申し上げる。

\section{交 献}

64) $H . J$. Tata, E. R. Driscoll. and $J \cdot J$. KARY: SAE Paper 800480 (1980)

65) 高橋 渖, 佐藤俊明, 堺 義宏, 緵田偷彦: 電気 製鋼，51 (1980)，p. 143

66) 梅沢信正：日経メカニカル，(1979) 4-2, p. 56

$67)$ 大森幹男，伊藤卓雄：鉄と鋼，63(1977), p. 1750

68) 小柳 愷：自動車技術，32(1978), p. 752

69) J.F. Kosis, and W.M. MAtlock: Metal
Prog., 108 (1975) 3, p. 58

70) 未発表（富士バルブ(株), TRW Valve Div.)

71) D. R. Jones: SAE Paper 800315 (1980)

72) A. J. Hickl: J. Metals, 32 (1980) 3, p. 6

73) D. Godfrey, and R. L. Gourtney: SAE Paper 710356 (1971)

74) $W$. Giles: SAE Paper 710368 (1971)

75）宮川大海：学振 123 委員会研究報告, 18 (1977) 3 , p. 143

76) 大沢 恂：ステンレス, 17(1973) 6, p. 2

77) R. K. Pitler: Proc. Alloys for the $80 \mathrm{~s}$ (1980), Paper no. 25 Climax Mo Co.

78) 佐味弘之, 柳原弘道: 自動車技術, 33(1979) 1, p. 49

79) $W$. Brandstetter: SAE Paper 800456 (1980)

$80)$ 斎藤 孟：機械の研究, 32(1980), p. 143

81）特公昭 54-24214, 出願人, 大同特殊鋼 (株)

82) 山口俊介，阔崎 健：自動車技術，34(1980), p. 723

83) 特許願：昭 54-41020，出愿人，大同特殊鋼 (怢) 及び富士バルブ(株)

84）未発表（大同特殊鋼）

85) International Nickel Co., Catalogue Datum, 2nd Ed., (1968)

86）西山利弘，宮下直也：自動車技術，26(1972), p. 198

87) 中川威雄：自動車技術，33(1979), p. 116

88) V. A. Tracey: Powder Met. Tech., 12 (1976), p. 25

89）五十嵐伊勢美：電子材料， 18 (1979) 5, p. 48

90) 小沢大成: 機械の研究, 32(1980), p. 191

91）壷井芳颔，本城雅則：自動車技術，33(1979), p. 54

92) 坂本光雄：特殊鋼， 28 (1979) 8, p. 11

93) H. U. Poмаск: IIW., 1976-MTC, 16-2-1

94) 竹内有公，洞田 亮：電気製鋼，51(1980), p. 34

95) 山本維行, 清野 洋, 羽室 憲, 外園保治: 日産 技報，(1977) 12，p. 71

96) $S . W$. MaGee and $F . K$. Burgers: The Int'1 J. of Powder Met. and Powder Tech. 12 (1976) 4, p. 313

97) C. Tsumiki: SAE paper 750409 (1975)

98) A. Kasak, and E. J. Dulis: Powder Met., (1978) 2, p. 114

99) J. A. Rassenfoss: SAE paper 800309 (1980)

100) H. E. Chandler: Met. Prog., 117 (1980) 6, p. 24

101）加藤哲男, 草加勝司：日本金属学会々報, 18 (1979), p. 624

102）加藤哲多，草加勝司：鋊と业鉛，9 (1972) 6, p. 8 